\title{
Türkiye'de Büyükşehir Yönetimlerine İlişkin Değişim ve Dönüşüm
}

\author{
Change and Transformation of the Metropolitan Municipality in Turkey
}

\section{Yakup BULUT}

Prof. Dr., Gaziantep Üniversitesi, İ̈BF,

Siyaset Bilimi ve Kати Yönetimi Bölümü,

yakupbulut@hotmail.com

https://orcid.org/0000-0002-0838-4200
Makale Başvuru Tarihi: 26.07.2020

Makale Kabul Tarihi: 31.08 .2020

Makale Türü: Araştırma Makalesi

\section{Demet DÖNMEZ}

Dr. Ögrr. Üyesi, Hatay Mustafa Kemal Üniversitesi, Antakya MYO,donmezdemet@gmail.com

https://orcid.org/0000-0002-5833-9088

\section{ÖZET}

Anahtar

Kelimeler:

Kentsel Alan

Yönetimi,

Büyükşehir

Belediyesi,

Türkiye,

Keywords:

Urban Area

Management,

Metropolitan

Munucipality,

Turkey,
Yerel hizmetlerin etkin ve verimli bir şekilde yerine getirilebilmesi aslında hizmetleri sunan birimlerin ve kurumların varlık nedenidir. Bunların başında, dünyadaki değişim ve dönüşüme paralel olarak büyüyen şehirler ve onların yönetimleri gelmektedir. Bu nedenle Türkiye'deki belediye yönetimlerine ilişkin gelişme, özellikle büyükşehir yönetimleri açısından her zaman gündemde olmuştur. Bunun temel sebebi, kentlere olan nüfus hareketliliği ve büyük şehirlerin hemen her alanda artan sorunlarıdır. Çalışmanın konusu; Türkiye'de bir alan yönetimi görünümüne sahip olan büyükşehir belediyelerinin değişim ve dönüşümünün incelenmesidir. Çalışmanın amacı büyük nüfuslu kentsel alan yönetimleri için geliştiren özel yönetim şeklinin (büyükşehir belediye modeli) etkinlik ve verimliliğinin değerlendirilmesi ve gelecek modeller için önerilerde bulunmaktır. Makalede, yürürlükteki hukuk normlarının tarihsel bir süreç içerisinde analizi yapılmıştır. Ayrıca bu dönemde kanunlaşan düzenlemeler ile birlikte kabul edilen büyükşehir yönetim modelleri değerlendirilmiştir.

\section{ABSTRACT}

Being able to perform local services effectively and efficiently is actually the reason for the existence of units and institutions that provide services. The most important of these are the cities and their administrations, which are growing in parallel with the change and transformation in the world. For this reason, the development of municipal administrations in Turkey has always been on the agenda, especially in terms of metropolitan administrations. The main reason for this is the population mobility in cities and the increasing problems of big cities in almost every field. The subject of the study is to examine the historical development and transformation of metropolitan municipalities with large-scale urban area administrations in Turkey. The aim of the study is to evaluate the effectiveness and efficiency of the special management style (metropolitan municipality model) developed for urban area administrations with large populations and to make suggestions for future models. In the article, the current legal norms were analyzed in a historical process. In addition, the metropolitan management models adopted with the regulations enacted in this period were evaluated.

* Bu makale ikinci yazarın, Prof. Dr. Yakup BULUT (birinci yazar) danışmanlığında hazırlanan ve 2018 yılında Mustafa Kemal Üniversitesi Sosyal Bilimler Enstitüsünde sunularak kabul edilen "Türkiye'de büyükşehir yönetimleri ve büyükşehirlerin yeniden yapılandırılmasına ilişkin model arayışları üzerine bir inceleme" başlıklı doktora tezinden faydalanılarak hazırlanmıştır. 


\section{GİRIŞ}

Türkiye'de belediye yönetimlerine ilişkin ilk ve kapsamlı düzenleme, 1930 y1lında kabul edilen 1580 sayılı Belediye Kanunu ile olmuştur. Söz konusu kanun belediye yönetimlerine ilişkin önemli yapısal ve işlevsel yenilikler ortaya koymakla beraber büyükşehirler ile ilgili herhangi bir düzenleme öngörmemiştir. Doğrudan olmasa da büyük şehir yönetimlerine ilişkin düzenlemelerin ilk olarak 1854 İstanbul Şehremanetinin kurulmasıyla ortaya çıkmaya başladığı görülmektedir. Diğer bir yaklaşımla 1854 yılında kurulan İstanbul Şehremaneti, İstanbul'un şubelere ayrılması ve sonraki yıllarda yapılan benzer düzenlemeler, bu şehrin farklı alanlarda artan sorunlarına çözüm bulabilmek amacı taşıyan büyük yerleşim yerleri için bir model arayışı olarak değerlendirilebilir. 1950'li yıllardan itibaren yaşanan hızlı kentleşme, özellikle nüfusun büyük şehirlere göç etmesi, büyük şehirlerin yönetimlerinde çok daha özel düzenlemeleri zorunlu kılmıştır. Büyükşehirlerin yönetimlerine ilişkin düzenlemeler, bugüne kadar yapılan yerel yönetim reformları içerisinde bu nedenle ayrı bir öneme sahiptir. Büyük şehirlerin her geçen gün artması, ihtiyaç duyulan hizmetlerin niteliğinde de değişimi gerekli kılmaktadır. 1982 Anayasası ile başlayan süreçte büyük şehirler anayasal dayanağını bulmuş ve bu bağlamda büyük şehirlere yönelik düzenlemeler de birtakım değişikliklerle birlikte sürmüştür. Her ne kadar Türkiye'nin büyükşehir yönetim modeli ile tanışması 1984 yılında kabul edilen 3030 sayılı kanun ile olmuşsa da günümüz formunu alması daha sonra gerçekleştirilen reformlar ve bu reformların mevzuatsal düzenlemeleri ile söz konusudur.

Büyükşehir belediyelerinin kurulmasından sonra 2004 yılında kabul edilen 5216 sayılı Kanun ve 2008 y1lında kabul edilen 5747 sayılı Kanun, büyükşehirler ile ilgili yeni düzenlemeleri ve bazı dönüşümleri ortaya koymuştur. 2012 yılında da büyükşehir belediye sistemimizde büyük değişiklikler öngören 6360 sayılı Kanun ile bu süreç devam etmiştir.

6360 sayılı Kanun ile Türkiye'de büyükşehir belediyelerinin görev ve yetki sınırı merkez ilçe sınırlarından il mülki sınırlarına genişletilmiştir. Ayrıca kasaba belediyeleri ve yine merkezde yer alan bir kasaba belediyesi formu olan ilk kademe belediyeleri ile köylerin tüzel kişilikleri ortadan kaldırılarak mahallelere dönüştürülmüştür. Hatta fiili etkinliği kalmayan ve Türkiye'de merkezi idarenin en küçük taşra birimi olan bucak idaresinin büyükşehirlerdeki hukuki varlıkları da sona erdirilmiştir. Bucakların, büyükşehir olmayan illerdeki hukuki varlıkları da 2004 yılında yürürlüğe giren 6552 sayılı kanun ile son bulmuştur. Yine büyükşehir olan illerde mevcut olan il özel idarelerinin tüzel kişilikleri de 6360 sayılı kanun ile ortadan kaldırılmıştır.

6360 sayılı Kanun ile yapılan değişiklikler ile büyükşehir belediyesi içerisinde iki basamaklı bir yerel yönetim mekanizması tesis edilmiş ve diğer yerel yönetim birimleri ortadan kaldırılmıştır. Büyükşehir ve ilçe belediyeleri arasında belirgin bir görev ve yetki paylaşımına gidilmiştir. Özellikle il özel idarelerinin kaldırılması ve köy tüzel kişiliklerinin son bulması ile en büyük kentsel alan yönetim birimi olan büyükşehir belediyeleri, kırsal alan yönetimi konusunda da görevlendirilmiştir. Hukuken kırsal alanlar kentsel alana dönüşmüş olsa da fiilen ve fiziken kırsal alan olarak yaşam sürülen bu alanların başta alt yapı olmak üzere birçok hizmeti doğrudan büyükşehir belediyeleri tarafından gerçekleştirilmeye başlamıştır. İmar ve planlamaya ilişkin düzenlemeler bunların en başında gelmektedir.

Büyükşehirlerin bir bütün olarak ele alınması, kent hizmetlerinin de bir bütün olarak ele alınıp sevk ve idare edilmesi ihtiyacını gündeme getirmekte ve bu da yeni ve farklı yönetim modellerinin geliştirilmesini zorunlu kılmaktadır. Yerel, bölgesel, ulusal ve hatta küresel gelişmeler kentsel kamu hizmetlerinin türünü, çeşitliliğini, önem sırasını, boyutunu ve sunma şekillerini de doğrudan doğruya etkilemektedir. Toplumsal, siyasal ve ekonomik gelişmeler ile kentsel alan yönetiminde yeni reformlara gidilmektedir. Bu bağlamda da son dönemlerde büyükşehir belediyelerinin görev ve yetkileri ile ilgili kamuoyunda birçok tartışmalar ileri sürülmektedir. Arz - talep ilişkisi içerisinde ve kamuoyu desteği ile bu konuda birçok yeni düzenlemelerin yapılacağı düşünülmektedir. Ancak bilimsel açıdan çok yönlü bu tartışmaların ve değişiklik çalışmalarının derin analizi yerine hukuken yürürlüğe girmiş mevzuatın değerlendirilmesi daha uygun görülmüştür. Çalışma ile büyükşehir belediye sistemi, döneme ait kanun değişiklikleri ve özellikle 2004 yılı sonrasında hız kazanan model arayışları ana hatları ile aktarılmaya çalışılmıştır. 


\section{TÜRKIYE'DE BÜYÜKŞEHİR BELEDIYYECILIĞİNE GEÇİŞ SÜRECİ VE BÜYÜKŞEHİR YÖNETIMLERINIIN KURULMASI}

Türk yönetim tarihi içerisinde modern anlamda kentsel alan yönetimleri 1854 y1lında İstanbul Şehremaneti’nin kurulması ile başlamıştır. Tanzimat dönemi ile başlayan bu gelişmeler Osmanlı Devletinden Türkiye'ye bir yönetsel miras olarak aktarılmıştır. Ancak cumhuriyet öncesi dönemdeki kentsel alan yönetimleri günümüz belediye yönetimlerini karşılamaktadır. Büyük ölçekli kentsel alan yönetimleri olarak değerlendirilebilecek bir yönetim modeli ve hukuksal düzenleme bu dönemde gerçekleştirilememiştir. Dolayısıyla büyükşehir belediyelerinin hukuki ve fiziksel olarak tesisi ve yönetilmesi cumhuriyet dönemi ile birlikte söz konusu olmuştur.

Cumhuriyet döneminde büyükşehir yönetimlerini genel anlamda üç alt dönemde incelemek mümkündür. İlk olarak 3030 sayılı kanuna kadarki durum ve 3030 sayılı kanunun kabulü, 5216 sayılı kanun ve büyükşehir belediye modeli ve son olarak 6360 sayılı kanun ile gelen reformlardır. Diğer taraftan büyükşsehir yönetim sisteminde özellikle ölçek reformu olarak değerlendirilebilecek olan 5747 sayılı düzenlemenin de önemini ayrica ifade etmemiz gerekmektedir.

\subsubsection{Sayılı Kanuna Kadarki Durum}

Türkiye'de belediyelerle ilgili kapsamlı düzenlemeler 1930 yılında çıkarılan 1580 sayılı Belediye Kanunu ile birlikte başlamıştır. Büyük şehirler için herhangi bir düzenleme öngörmeyen bu kanunda İstanbul için özel bir yönetim şekli getirilmiştir. Buna göre İstanbul Belediyesi, İstanbul İl Özel Yönetimi ile birleştirilmiştir. Bu Ortak Yönetimin başında, aynı zamanda İstanbul Belediye Başkanı olarak da görev yapan ve merkezi yönetimce atanan bir vali bulunmaktaydı. İstanbul Ortak Yönetimi'nin halkın oyu ile seçilen üyelerden oluşan bir Encümeni mevcuttu. 1956 yılına kadar varlığını koruyan bu yapı, bu yıldan itibaren hem belediyeye, hem de il özel yönetimine diğer belediyelerde olduğu gibi, ayrı ayrı seçilmiş meclislere sahip olma yetkisi vermiştir (Keleş, 2009:309). Bu uygulama yalnızca bizim yönetim geleneğimizde görülen bir uygulama değildir. Aynı sistem Paris'te de uygulanmıştır ve 1970 yılında sona ermiştir (Turan, 2008:24).

Türkiye'de yeni bir Anayasayla başlayan 1961-1980 dönemi, birçok konuda planlama dönemi olarak bilinmektedir. Özellikle, beş yıllık kalkınma planlarında kentsel sorunlar sıklıkla yer almış, metropoliten alan olarak adlandırılan büyük kent alanları için çeşitli öneriler getirilmiştir (Çukurçayır, 2011:246). Ancak bu önerilerin çoğu yetersiz ve sonuç odaklılıktan uzaktır. Büyük şehir model arayışları tekrarlanan önerilerden ibaret kalmıştır.

1961 Anayasası'nın 116. maddesi, yerel yönetimlerin karar organlarının seçimle iş başına gelmeleri gerektiğini belirtmiştir. Ayrıca 1961 Anayasası ile merkezi idareye belediye başkanı atama yetkisi de tanınmıştır. Ancak merkezi yönetimler bu atama yetkilerini nadiren kullanmışlardır. Örneğin, 1960-1964 yılları arasında İstanbul'a yalnızca üç yıl için belediye başkanı atanmıştır. Genel olarak belediye başkanının seçimle iş başına gelmesi yoluna gidilmiştir (Keleş, 2000:275).

1961 Anayasası, büyükşehir yönetimi kurulması için elverişli değildi. Ancak, 116. maddede yer alan mahalli idarelerin kendi aralarında birlik kurabilmeleri ile ilgili hüküm, belediyelerin 1960-1980 yılları arasında birlikler kurmasına imkân sağlamıştır. 1580 sayılı Belediye Kanunu da birliklerle ilgili hüküm getirmiştir. 1580 sayılı Belediye Kanunu'nun 133. maddesi, birliklerle ilgili hükümde şöyle demektedir: Belde ve köyler, il özel yönetimleri zorunlu veya seçimlik görevlerinin bir veya birkaçını ortak kuruluş ve idare ile yerine getirmek için aralarında birlikler kurabilirler. Bu hükme dayanarak, birkaç belediye bu dönemde birlikler kurmuşlardır. Ancak bunlar büyükşehir yönetimlerinin yapacağı kapsamlı hizmetleri yapmaktan uzaktırlar. Çünkü büyükşehir yönetimleri tek tek bazı hizmetlerle değil, büyükşsehir alanındaki bütün kamusal hizmetlerin yürütülmesi sorumluluğunu üstlenirler (Keleş, 2009:310).

Büyük şehirler için özel yönetim birimleri oluşturmak amacıyla, 1965 yılından itibaren Bakanlar Kurulu kararıyla İstanbul, İzmir ve Ankara'nın nazım planlarını hazırlama çalışmalarını yürütmek üzere, İmar ve İskan Bakanlı̆̆ı'na bağlı olarak Metropoliten Planlama Büroları kurulmuştur (Çukurçayır, 2011:247). 1972 yılında da Bakanlar Kurulu Kararı ile imar konusunda bir bütünlük sağlamak ve büyük şehirlerin sorunlarını metropoliten kuruluşlar yoluyla çözmek amacıyla Bakanlıklar arası İmar Koordinasyon Kurulu oluşturulmuştur (Kavruk, 1999:196). Yine 1972 yılında İçişleri Bakanlığ Tasarısı", 1975 yılında İçişleri Bakanlığı tarafından hazırlanan "İstanbul Metropoliten Hizmet Birliği Yasa 
BULUT, Yakup ve DÖNMEZ, Demet - Türkiye'de Büyükşehir Yönetimlerine İlişkin Değişim ve Dönüşüm

Tasarısı", 1979 yılında Bakanlar Kurulu tarafindan "Planlama ve Eşgüdüm Kurulunun” Kurulması, 1980 yılında İçişleri Bakanlığı ve İskan Bakanlığı tarafından hazırlanan "Büyükkent Birliği Yasa Tasarısı" ve 1980 yılında "2561 sayılı Büyükşehirlerin Yakın Çevresindeki Yerleşim Yerlerinin Ana Belediyelere Bağlanması Hakkında Yasa", metropoliten yönetimlerin oluşturulmasına yönelik hazırlanan çalışmalar ve kanuni düzenlemelerdir (Özçelik, 2014:1122-1123). Bu dönem, yerel yönetimler üzerinde merkeziyetçi ağırlığın yoğun olarak hissedildiği bir dönem olarak değerlendirilebilir. Hatta kısa bir süre Yerel Yönetim Bakanlığı dahi kurulmuştur. Bu bakanlığın belediyeleri teftiş dahi ettiği, böylece ağır bir merkeziyetçi rolünün olduğu ifade edilebilir. $\mathrm{Bu}$ dönemde, büyük şehirlerin sorunlarına çözüm olması açısından hazırlanan tasarılar yasalaşmamıştır.

Büyükşehirlerin sorunlarını etkin ve verimli bir biçimde çözmeye yönelik yapılan tasarı ve teklifler için Eke (1982:175-177), şöyle bir değerlendirme yapmaktadır;

1. Görevlerin Merkezi Yönetim Tarafindan Üstlenilmesi: Bu seçenek "mansup belediye başkanlığı" ve bazı belediye başkanlıklarının valiliklerce yürütülmesi dolayısıyla uygulama imkanı bulmuştur. Bu durum işbirliği ve koordinasyon bakımından faydalı olsa bile, büyükşehir alanındaki sorunlara uzun vadeli ve köklü bir çözüm olarak düşünülmediği gibi, demokratikleşme sürecinde de fazla ilgi görmesi mümkün değildir.

2. Özel Amaçlı Örgütler: Bu yöntem çok sık olmasa da uygulama alanı bulmuştur. DDY, İETT, EGO gibi örgütler kent içi bazı hizmetleri yerine getirdiklerinden dolayı bu grupta düşünülmektedir. Ancak bu örgütlerin tek çeşit hizmet sunduğu ve kentsel sorunların bağımlılığı göz önüne alınmadığından dolayı, kapsamlı çözüm olmaktan uzak kalmışlardır.

3. Hizmet Birlikleri: Bu dönemde anayasal çerçevenin, büyükşehir ölçüsünde kentsel birliklere izin vermesi, çıkar yolun bu olduğunu göstermiştir.

4. İ Özel İdarelerinden Yararlanmak: ABD, İngiltere, Kanada gibi Batılı ülkelerde, büyükşehirde mevcut sorunları çözmeye yönelik olarak izlenen yol merkezi yönetimle yerel yönetim arasına, orta düzey genel amaçlı örgütler kurmaktır. Bizde de bu örgütlerin İl Özel idareleri olduğu ileri sürülmüsstür. İl Özel İdarelerinin bütün kenti kapsaması ve aracı bir yönetim konumunda bulunması, bu işlevi yerine getirebileceğini göstermektedir Bu öneri, büyükşehir sorunlarını salt planlama sorunu olarak ve sadece İstanbul için ele almıştır. Sorun, planların uygulanmasında, kaynak ve hizmetlerde denge sağlanmasında, kentsel hizmetlere olan talep-arz arasındaki boşluğun doldurulması sorunudur.

5. Federasyon: Federasyon örgütlenme biçimine göre, İstanbul'da büyükşehir belediyesi kurulup, İstanbul belediyesinin optimum büyüklüklere bölünüp var olan belediyelerle bir üst belediyenin kentsel hizmetleri birlikte yürütmeleri gerektiği savunulmuştur. Üst belediye planlama ve bölgesel nitelikteki hizmetleri yaparken, küçük belediyeler de ikincil nitelikteki hizmetleri yürütecektir (Çukurçayır, 1994:66).

12 Eylül 1980 askeri müdahalesi sebebiyle bu dönem "ara rejim” dönemi olarak bilinmektedir. Büyükşehirlerin sorunlarına çözüm bulmak amacıyla özel yönetim biçimleri oluşturma yoluna gidilmiş ve çok sayıda hukuksal düzenleme yapılmıştır. Yine bu dönemde askeri yönetimin iki önemli kararı vardır. Bunlardan birincisi, belediye organlarının tüzel kişiliklerinin kaldırılması ve belediye başkanlarının atanması ile ilgilidir. Belediyelerin tüzel kişiliklerinin kaldırılması yönündeki düzenleme Milli Güvenlik Konseyi’nin 34 sayılı kararı ile ve küçük yerel yönetim birimlerinin sayıca azaltılması amacıyla gerçekleştirilmiştir. Bu düzenlemenin gerekçesi şöyledir;
“Ülkemizdeki (Türkiye’deki) hızlı nüfus artışı ve köyden kente göçün sonucu olarak büyük kentlerimizin yakınlarında teşekkül etmiş belediyeler; aydınlatma, su, kanalizasyon ve ulaşım gibi hizmetlerin yeterli bir şekilde halka götürülmemesine ve kontrolün aksamasina neden olmaktadır. Büyük kentlerin çevresinde teşekkül etmiş bulunan bu durumdaki belediyelerin, Slkıyönetim Komutanlıklarının koordinesinde ve onların emredecekleri şekilde ana belediyelere bağlanması bir plan dahilinde ve en kisa zamanda sağlanacaktır".

Bu kararın uygulanması sonucu, 1980 yılında 1700 olan belediye sayıs1, 1981'de 1580'e düşmüştür. 150 kadar köyün de tüzel kişiliklerine son verilmiştir. Bu karar askeri otoritelerce farklı uygulamalara konu olduğundan, 1981 yılında 2561 sayılı birleştirme yasası çıkarılmıştır. Bu düzenleme, nüfusu 300 bin ve üzerinde olan kentleri kapsamıştır. Bu kentler İstanbul, İzmir, Ankara, Adana, Bursa, Gaziantep, Konya ve Eskişehir'dir (Keleş, 2009:311-312).

2561 sayılı, Anakentlerin Yakın Çevresindeki Yerleşim Yerlerinin Ana Belediyelere Bağlanması Hakkındaki Kanun'un düzenleme alanını, enerji, içme ve kullanma suyu, kanalizasyon, ulaşım, toplu taşıma ve imar gibi 
temel belediye hizmetleri olarak ifade etmek mümkündür. Ayrıca bu hizmetlerin birbiri ile uyumlu ve bütünleştirici bir planlama içinde verimli bir şekilde yerine getirilmesi amacı vardır (Çukurçayır, 2011:249). Diğer taraftan ilgili yasanın içerdiği tüzel kişiliklerin son bulmasının Anayasaya uygun olup olmadığı tartışması yapılmıştır. Ancak, bu sorun Anayasa Düzeni Hakkındaki Yasayla çözülmüştür. Bu yasaya göre, Milli Güvenlik Kurulu'nun çıkarmış olduğu kararlar, yürürlükteki yasalarla çeliştiğinde, Anayasa ve yasa değişikliği yerine geçebilecekti. Bu dönemde belediye şubeleri kurma yoluna da gidilmiştir. Bugünkü büyükşehirlerde yer alan ilçe belediyeleri gibi olan belediye şubeleri, ilk olarak İstanbul'da kent içinde ve dışında bulunan 13 belediyenin tüzel kişiliği kaldırılarak gerçekleştirilmiştir. Diğer illerde de benzer şekilde şube kurma yoluna gidilmiştir (Tortop, 1991:174).

Askeri yönetimin ikinci önemli kararı da belediyelerin kaynak sıkıntısını gidermeye yönelik olanıdır. 1981'de yürürlüğe giren 2380 sayılı "Belediyelere ve Il Özel İdarelerine Genel Bütçe Vergi Gelirlerinden Pay Verilmesi Hakkında Kanun" bu düzenlemeyi getirmiştir. Belediyelere genel bütçe vergi gelirlerinden \%5 oranında pay verilmesi ve bu payın belediyelerin nüfusuna göre bölüştürülmesini hükme bağlayan yasa, belediyeleri oldukça rahatlatmıştır. Ancak, yerel yönetimlerin öncelikli harcamalarının ve daha sonra da gelirlerinin belirlenmesi ilkesine uyulmadığından uygulanan yöntem rasyonel olmamıştır (Nadaroğlu, 1989:302).

\subsubsection{Sayılı Kanun ve Büyükșehir Belediye Yönetimlerinin Kuruluşu}

Türkiye'de büyükşehir belediyelerinin kurulmasında dünyadaki farklı biçimlerde yaşanan metropolleşme olgusunun önemi büyüktür. Belediyelerin büyüklüğü farketmeksizin hepsi 1930 yılından itibaren 1580 sayılı Kanuna göre yönetilmiştir. 3030 sayılı Kanunla birlikte büyük yerleşim yerleri için özel yönetim biçimleri getirilmiştir. 3030 sayılı kanunla ortaya konan modelin Londra, Toronto ve Tokyo'nun yönetim modelinden esinlendiği söylenebilir (Şengül, 2010:108).

Büyükşehir düzenlemesinin temeli ve bu güne kadar Türkiye'de büyük şehirlerde özel yönetimler kurulması gereğini tamamlayıcı şekilde 1982 Anayasası'nın 127.maddesinde, “Kanun büyük yerleşim merkezleri için özel yönetim biçimleri getirebilir", hükmü yer almıştır. Bu hükme istinaden 1984 yılında yürürlüğe giren 195 sayılı Kanun Hükmünde Kararname ile büyükşehir belediye yönetimi düzenlenmiştir.

Büyükşsehirlere ilişkin çıkarılan 195 sayılı Kararnamede büyükşsehir tanımlaması için Anakent Belediyeleri Hakkında Kanun Hükmünde Kararname Tasarısında yer alan 500.000 nüfus şartı dikkate alınmamış ve söz konusu kararnamede "belediye sinırları içinde birden fazla ilçe bulunan şehirler" büyükşsehir olarak tanımlanmıştır. Bu çerçevede İstanbul, Ankara ve İzmir'de büyükşsehir belediye yönetimleri kurulmuştur (Öner, 2006:255; Bayrakc1, 2019:160-161).

195 sayılı KHK yayınlandıktan kısa bir süre sonra büyükşehir belediye yönetimi 27 Haziran 1984 tarihinde 3030 sayılı Kanun ile hukuki bir statü kazanmıştır. 3030 sayılı Kanun'da büyükşehir kavramı; "belediye sınırlarl içinde birden fazla ilçe bulunan şehirler", olarak tanımlanmıştır (md.3/1). Ayrıca kanunda büyük şehrin adı ile bir büyükşehir belediyesi, büyükşehir dahilindeki ilçelerde ise ilçe isimlerini taşıyan "ilçe belediyeleri” kurulması hükme bağlanmıştır (md.4/1). Bunlar birer tanımdan ibaret olup, kuruluş şekli ile ilgili bir açıklama yoktur (Bulut, 1995:89). Böylece Türkiye'de büyükşehirlerde 2 kademeli bir belediye yönetimi modeli ortaya çıkmıştır.

Kanun hükmünün uygulanması ile birlikte ortaya çıkan iki kademeli modelin birincisi, 1580 sayılı Kanuna tabi olarak yönetilen ve normal belediyeler olarak adlandırılan belediye yönetimleri; İkincisi ise 3030 sayılı Kanuna tabi büyükşehir belediyeleri ve bu model içinde kurulan ilçe ve alt kademe belediyeleridir (Öner, 2006:255). 3030 sayılı Kanunun getirdiği, "büyükşehir belediyesi" ve "ilçe belediyesi" statülerinden farklı olarak, büyükşehir belediyesi sınırları içinde "alt kademe belediyeleri”nin kurulmaları öngören düzenleme 2 Eylül 1993 tarih ve 504 sayılı KHK ile yürürlüğe girmiştir. Kavruk (1999:219)'a göre, alt kademe belediyesi kavramının, 3030 sayılı Kanunla, içerisinde birden fazla ilçe bulunan şehirler olarak tarif edilen büyükşehir belediyelerini, içerisinde birden fazla ilçe olmayan başka illerde de kurabilmeyi kolaylaştırmak için geliştirildiğini belirtmiştir.

Büyükşehir belediyelerinin yönetimini düzenleyen 3030 sayılı Kanun, büyükşehir yönetiminin hukuki statüsünün amacının hizmetlerin planlı, programlı, etkin ve uyum içinde yürütülmesinin sağlanması olduğunu belirtmekteydi (md. 1). Kanun, büyükşehir belediyeleri ile ilçe belediyelerinin kuruluş, görev ve yetkilerini, merkezi idareler ile diğer mahalli idareler ile ilişkilerini düzenleme amacını taşımaktaydı (md.2).

Türkiye'de büyükşehirler için oluşturulan bu düzenleme ile ilçelerin ve beldelerin yerelliklerinin korunarak, halkın yönetime katılması ve yerel demokrasinin geliştirilmesi amaçlanmıştı. Yine büyükşehir sınırları 
içerisinde birbirleri ile ilişkili yerel kamu hizmetlerinin gerçekleştirilebilmesi için belediyeler arasında koordinasyonun sağlanması da kanunun amaçları arasındaydı. Böylece "ekonomik" yönden büyük ölçekli birimlerin avantajlarından yararlanılmaya çalışıldığı gibi, ilçe/belde belediyelerine de yer verilmekle “demokratik" yönden küçük ölçekli birimlerin etkinliğine önem verilmiş olacaktı (Eryılmaz, 2012:205). Bu modelde, üst kademe ağırlıklı biçimde tasarlanmıştır. Büyükşehire oldukça önemli yetkiler ve kent bütünlüğüne yönelik hizmetler üst kademeye verilmiş, daha yerel nitelikte ve daha katılıma duyarlı olduğu düşünülen hizmetler alt kademeye bırakılmış, diğer taraftan da büyükşehir belediyesine koordinasyon görevi de verilerek hizmetlerin planlı, programlı, verimli ve etkin bir şekilde sunulması amaçlanmıştır (Özçelik, 2014:1124; Arıkboğa, 2012:5; Y1lmaz, 2018:4365).

Türkiye'de büyükşehir olma sürecinde, üst kademe değil aslında alt kademe kurulmuştur. Örneğin Bursa'da Bursa Belediyesi, büyükşehire dönüşmüş ve büyükşehir sınırı içinde üç yeni ilçe belediyesi oluşturulmuştur (3391 sayılı Kanun). Dolayısıyla, dile getirildiği gibi, "üst kademe sadece koordinasyonla sorumlu olsun, alt kademe ise çok daha fazla alanda yetkili olsun" şeklindeki öneriler temenni olarak kalmıştır (Arıkboğa, 2012:5).

3030 sayılı Kanun uygulama noktasında değerlendirilecek olursa modelde birtakım güçlüklerle karşılaşıldığını söylemek mümkündür. Bu güçlüklerin büyük bir kısmı, Türk Kamu Yönetiminin geleneksel merkeziyetçi yapısının bir sonucudur. Tüm yerinden yönetim çabalarına karşın, merkezi idare yerel birimler üzerinde güçlü bir vesayet yetkisine sahip olmuştur. Vazgeçebileceklerini ise, büyükşsehirlerde tümüyle bırakmayıp, ilçe belediyeleri üzerinde kullanılmak üzere büyükşehir belediyelerine terk etmiştir. $\mathrm{Bu}$ da büyükşehirlerde vesayetin kendisinin değil, kullanıcısının değiştiğini göstermektedir (Ökmen ve Parlak, 2008:200; Keleş, 2011:331).

Kanunun uygulanmasına yönelik olarak diğer bir eleştiri konusu, kanunun demokratik ve katılımcı yönetim anlayışını ikinci plana atmasıdır. Yani mevcut nüfus ve alan bölünüşü, yerel demokrasiyi gerçekleştirecek katılıma imkan veremeyecek durumdaydı. Yönetim alanının geniş olması belki ekonomik ve yönetsel etkinliği sağlamakta ancak demokratik denetimi ve katılımı zorlaştırmaktaydı (Bulut, 1999:55).

Mevcut tüm bu sıkıntılara rağmen, 1984 yılından bu yana büyükşehir belediyesi yönetiminin zaman içinde hızla yaygınlaşma eğilimi gösterdiği söylenebilir. İlk defa 25 Mart 1984 günü yapılan mahalli idare seçimleri ile üç büyük şehirde (İstanbul, Ankara, İzmir) büyükşehir belediyesi oluşmuşken 19 Haziran 1986 gününde Resmi Gazete'de yayınlanan 3306 sayılı Kanunla Adana'da büyükşehir belediyesi kurulması kararlaştırılmıştır (Tortop vd., 2008:262). Daha sonra çıkarılan kanun ve KHK' ler ile büyükşehir yönetimleri artmıştır. Bugün Türkiye'de toplam 30 Büyükşehir belediyesi bulunmaktadır. Bu şehirlerimiz; Adana, Ankara, Antalya, Aydın, Balıkesir, Bursa, Denizli, Diyarbakır, Erzurum, Eskişehir, Gaziantep, Hatay, İstanbul, İzmir, Kahramanmaraş, Kayseri, Kocaeli, Konya, Malatya, Manisa, Mardin, Mersin, Muğla, Ordu, Samsun, Sakarya, Şanlıurfa, Tekirdağ, Trabzon ve Van'dır.

Tablo 1. Büyükşehir Belediyelerinin Kuruluş Tarihleri

\begin{tabular}{|c|c|c|}
\hline ILGILİ DÜZENLEME & YIL & BELEDIYYE \\
\hline 3030 say11 Kanun & 1984 & İstanbul, Ankara, İzmir \\
\hline 3306 say11 Kanun & 1986 & Adana \\
\hline 3391,3398 ve 3399 sayılı Kanunlar & 1987 & Bursa, Gaziantep, Konya \\
\hline 3508 say1lı Kanun & 1988 & Kayseri \\
\hline 504 sayılı KHK & 1993 & Antalya, Diyarbakır, Erzurum, Eskişehir, İzmit (Kocaeli), Mersin, Samsun \\
\hline 593 sayılı KHK & 2000 & Adapazarı (Sakarya) \\
\hline 6360 sayılı Kanun & 2014 & $\begin{array}{c}\text { Aydın, Balıkesir, Denizli, Hatay, Malatya, Manisa, Kahramanmaraş, } \\
\text { Mardin, Muğla, Ordu, Tekirdağ, Trabzon, Şanlıurfa, Van }\end{array}$ \\
\hline
\end{tabular}

3030 sayılı Kanun ile kabul edilen büyükşehir modeli, "güçlü başkan” yapılanmasını kurumsallaştırdığı gerekçesiyle eleştiri konusu olmuş ve bu noktada yerel demokrasi için kötü bir örnek olarak gösterilmiştir (Öner, 2006:259). Diğer taraftan bu kanunla kurulan büyükşehir belediye sistemimizde; görev ve yetkilerin paylaşılmasında nesnel ölçütler bulunmaması, yönetim kademeleri arasında işbirliği kurma mekanizmalarının yeterli olmaması, büyükşehir yönetiminin kesin bir hakimiyetinin bulunmaması, büyükşehir genelinde planlama ve koordinasyon yapılamaması ve belediye büyüklüklerinin çok farklı olması genel sorunların başında gelmiştir (Dedeoğlu, 2011:133; Ökmen ve Parlak, 2008:202). 
23 Temmuz 2004 tarihine kadar yürürlükte kalan 3030 sayılı kanun; yönetim yapısı ve tanımlara ilişkin getirilen ölçütler açısından da bazı sorunlar içermekteydi ve özellikle büyükşehir belediyelerinin kurulmasına ilişkin herhangi bir nesnel ölçüt bulunmamaktaydı. 3030 sayılı kanunda, büyükşehir belediyesi sınırlarının ilgili bakanlıklar ve kurumların yapacağ 1 çalışmalar doğrultusunda belirlenmesi öngörülmüş ve bu yapılanmaya ilişkin herhangi bir ölçüt tanımlanmamıştır (Özdemir ve Meşhur, 2011:175). Büyükşehirlerde, büyükşehrin adı ile bir "Büyükşehir Belediyesi", büyükşehir dahilindeki ilçelerde ise ilçelerin adını taşıyan "İlçe Belediyeleri" kurulur (md. 4) ve Büyükşehir Belediyelerinin sınırları, ismini aldıkları büyükşehirlerin belediye sınırlarıdır. İlçe Belediyelerinin sınırları, bu ilçelerin, büyükşehir belediyesi içinde kalan kısımlarının sınırlarıdır (md. 5) şeklinde düzenlenmiş, büyükşehir statüsüne ulaşmak için büyükşehir sınırları içerisinde birden fazla ilçe bulunmasını yeterli görmüştür.

\subsection{Sayılı Büyükşehir Belediyesi Kanunu ile Öngörülen Model}

Türkiye'de ilk defa 3030 sayılı kanun ile hayata geçen büyükşehir belediyesi sisteminin uygulama noktasında ortaya çıkan sorunları gidermek ve büyükşehir yönetimlerini daha etkin bir şekilde işleyen yapıya kavuşturmak amacıyla 5216 sayılı Büyükşehir Belediye Kanunu hazırlanmış ve kabul edilmiştir.

3030 sayılı kanun, 2004 yılında 5216 sayılı kanunla yürürlükten kaldırılmıştır. 5216 sayılı kanun, önceki kanunla kabul edilen iki düzeyli büyükşehir modelini devam ettirmiştir. 3030 sayılı Kanun döneminde büyükşehir belediyesi olabilmek için yerleşim yeri nüfusunun 300.000'nin üzerinde olması ve büyükşehir sınırları içerisinde birden fazla ilçe olması gerekiyordu. O dönemde bu şartları taşıyan iller sadece İstanbul, Ankara ve İzmir'di. Büyükşehir belediyelerinin artmasına yönelik talepler sonucunda 1993 yılında çıkarılan 504 sayılı KHK ile büyükşehir belediye sınırları içinde birden fazla ilçe olmayan yerler için farklı uygulamalara gidildi. Buralarda yeni ilçe oluşumu yerine alt kademe belediye uygulaması getirildi. Bu politika değişikliğinin temel sebebi, merkezi yönetimin yeni ilçeler kurmanın ağır maliyetine katlanmak istememesiydi (Şengül, 2010:109; Ulusoy ve Akdemir, 2001:179; Ökmen ve Parlak, 2008:201). 5216 sayılı kanun, büyükşehir belediyesini;

"en az üç ilçe veya ilk kademe belediyesini kapsayan, bu belediyeler arasında koordinasyonu sağlayan; kanunlarla verilen görev ve sorumluluklart yerine getiren, yetkileri kullanan; idari ve mali özerkliğe sahip ve karar organı seçmenler tarafindan seçilerek oluşturulan kamu tüzel kişisi", ilçe belediyesini, "büyükşsehir belediyesi sinırları içinde kalan ilçe belediyesi", ilk kademe belediyelerini ise "büyükşsehir belediye sınırlart içinde ilçe kurulmaksızın oluşturulan ve büyükşehir ilçe belediyeleriyle aynı yetki, imtiyaz ve sorumluluklara sahip belediyeler",

olarak tanımlamıştır (md.3). Kanun yürürlüğe girdiği tarihte, sadece İstanbul ve Kocaeli illerinde büyükşehir belediye sınırını, il mülki sınırı olarak belirlemiştir. Diğer büyükşehir belediyelerinde, mevcut valilik binası merkez kabul edilerek ve il mülki sınırları içinde kalmak şartıyla, nüfusu bir milyona kadar büyükşehirlerde yarıçap1 $20 \mathrm{~km}$, nüfusu bir milyondan iki milyona kadar olan büyükşehirlerde yarıçap1 $30 \mathrm{~km}$, nüfusu iki milyondan fazla olan büyükşsehirlerde yarıçapı $50 \mathrm{~km}$ olan dairenin sınırı büyükşehir belediye sınırı olarak kabul edilmiştir (Geçici md.2).

Büyükşehir belediyesi sınırlarının, 20,30 ve $50 \mathrm{~km}$. gibi uzaklıklar belirlenerek, bu yarıçap büyüklüklerine uygun olarak, kentlerin özelliklerine hiç bakılmaksızın, mekanik bir şekilde çizimini zorunlu kılan bu madde çok da gerçekçi değildi. "Pergel ile çizilmiş" gibi sınır belirlemek bilimsel temelden de son derece yoksundu. Ayrıca büyükşsehir belediyesine katılımı söz konusu olacak yerler için halkın oyuna başvurunun öngörülmemesi Avrupa Yerel Yönetimler Özerklik Şartı'na aykırı olduğundan, 2008 tarihinde yürürlüğe giren 5747 sayılı Kanun ile bu uygulamaya son verilmiştir (Keleş, 2011:315). 3030 sayılı Kanun'dan farklı olarak 5216 sayılı Kanun büyükşehir yönetimi kurulabilmesi için 750.000 nüfus şartını getirmiştir. Kanundaki tanım;

"Belediye sınırlart içindeki ve bu sinırlara en fazla 10.000 metre uzaklıktaki yerleşim birimlerinin son nüfus sayımina göre toplam nüfusu 750.000'den fazla olan il belediyeleri, fiziki yerleşim durumları ve ekonomik gelişmişlik düzeyleri dikkate alınarak, kanunla büyükşshir belediyesine dönüştürülebilir",

şeklindedir (md. 4). Bu tanımda, nüfus kriteri ile birlikte ekonomik gelişmişlik düzeyinin de koşul olması dikkat çeken bir ifade olarak kabul edilebilir.

Yeni düzenlemeler ile özellikle İstanbul ve Kocaeli başta olmak üzere aralarında Ankara, İzmir gibi diğer büyük kentlerin de bulunduğu pek çok büyükşehir belediyesi çok özel bir yapıya kavuşturulmuş, hizmet ve sorumluluk 
alanları genişletilmiştir (Olgun, 2006:112). Kanunda büyükşehir belediyelerinin görevleri tek tek sayılarak belirtildiğinden bunların dışında herhangi bir görev ve hizmet üstlenemeyecekler, ilçe ve ilk kademe belediyeleri ise bu görev ve hizmetler dışında kalan ve kanunlarla başka bir kuruluşa verilmeyen mahalli müşterek bütün görev ve hizmetleri yerine getirebileceklerdi (Dedeoğlu, 2011:134).

Kanun, yedi bölümde, 33 madde ve 5 geçici maddeden oluşmaktadır. Birinci bölümde, kanunun amacı, kapsamı ve tanımlar (madde 1-3); ikinci bölümde büyükşehir belediyesinin kuruluşu ve sınırları (madde 4-6); üçüncü bölümde büyükşehir, ilçe ve ilk kademe belediyelerinin görev ve sorumlulukları (madde 7-11) düzenlenmiştir. Dördüncü bölüm büyükşsehir belediyelerinin organlarını (madde 12-20) düzenlerken beşinci bölüm büyükşehir belediyesinin teşkilat yapısı ve personelini (madde 21-22) ele almıştır. Altıncı bölüm büyükşehir belediyesinin gelir ve giderleri, bütçesine ilişkin (madde 23-27), yedinci bölüm ise çeşitli hükümler (madde 27-33) başlığını taşımaktadır.

\subsection{Büyükşehir Belediyesinde 5747 Sayılı Kanun ile Gelen Değişiklikler}

1980'li yıllardan itibaren hızlı nüfus artışı ve yaşanan göçlere bağlı olarak yerleşim yerlerinin sayılarında ve nüfus yoğunluklarında önemli değişimler yaşanmış, nüfus büyük kentlerde yoğunlaşırken küçük yerleşim birimlerinde önemli ölçüde azalmıştır.

Nüfusu azalan kırsal alanlarda olumsuz gelişmeler yaşanmış ve hiçbir bilimsel temele dayanmayan ve tamamen siyasi yaklaşımlarla küçük yerleşim yerlerinin belediye haline getirilmesi süreci hızlandırılmış ve bunun sonucunda küçük yerleşim birimlerinin sorunları çok daha artmıştır. 2002 yılında yapılan bir araştırmada küçük belediyelerle ilgili olarak şu sonuçlar elde edilmiştir (Özçelik, 2014:1129);

- Küçük belediyelerin önemli bir kısmı, büyük belediyelerin (büyükşehir, il, ilçe) çevresinde toplanmıştır.

- Küçük belediyelerin birçok yerel kamu hizmetini yürütemedikleri görülmektedir.

- Küçük belediyelerde halkın katılım kapasitesi, belediyelerin katılımla ilgili ortam yaratma kapasitesi çok düşüktür.

- Küçük belediyelerde teknik eleman istihdam kapasitesi çok düşüktür.

- Küçük belediyelerin mali yapıları, genel bütçe vergi gelirlerine bağımlıdır. Öz gelir elde etme kapasitesi düşüktür ve cari harcamalar bütçe içinde çok büyük yer tutmaktadır.

Ekonomik ve toplumsal ilişkiler bakımından bütünlük arz eden merkez ve çevre belediyelerinde kamu hizmetlerinin ayrı ayrı belediyeler tarafından sunulması, hizmetlerin bölünmezliği ilkesine ters düşmekte, küçük küçük her belediyenin her hizmeti sunmak için kaynak ayırması savurganca bir yönetime sebep olmaktadır (Keleş, 2011:291).

Küçük belediyelerin kurulması ile ilgili en kapsamlı düzenleme 2005 yılında 5393 sayılı Kanun ile yapılmıştır. İlgili kanun ile küçük ve bu kadar sık belediye kurulmasının önüne geçilmiştir. Kanunda, belediye kurulabilmesi için 5000 nüfus şartının yanında, "meskun sahasının kurulu bir belediyenin sınırlarına 5000 metreden daha yakın olan yerleşim yerlerinde belediye kurulamaz" (md.4), denilerek küçük yerleşim yerlerinde belediye kurulmasına son verilmiştir.

Eski Kanun'da da (md.8) aynen kullanılan "meskun saha” kavramı ile ilgili olarak ihtilaf çıkmıştır. İkamet için kullanılan yerleşim alanı anlamına gelen kavramın, uygulamada, sürekli ikametgah olarak kullanılmayan geçici baraka ve fabrika gibi işyeri ve geçici barınakların da meskun saha olarak değerlendirilip değerlendirilemeyeceği tartışılmıştır. Danıştay, sadece ikamet amacına yönelik evler topluluğunun esas alınmasına karar vermiştir (Sezer, 2007:152).

5393 sayılı Belediye Kanunu ile yapılan değişikliğin yanı sıra, 5747 sayılı "Büyükşehir Belediye Stnırları İçerisinde İlçe Kurulması ve Bazı Kanunlarda Değişiklik Yapılması Hakkında Kanun" ile bazı önemli değişiklikler getirilmiştir. Bu iki kanun, yerel yönetimlerin ölçeklere yönelik olarak yaptığı en kapsamlı düzenlemeleri içermektedir.

5747 sayı1ı Kanun ile nüfusu 2000'in altına düşen belde belediyelerinin tamamı kapatılmış, büyükşehir belediye sistemimiz içinde yer alan ilk kademe belediyeleri uygulamasına son verilmiş ve büyükşehir belediyeleri iki kademeli sisteme (büyükşehir belediyesi + BŞB ilçe belediyesi) geri dönmüştür. Kanunun yürürlüğe girdiği 29 Mart 2009 Yerel Yönetim Seçimleri ile birlikte 16 büyükşehir belediyesi sınırları içinde yer alan 240 belde belediyesi mahalleye dönüştürülerek kapatılmıştır (Zengin, 2014:101). 
5747 sayılı Kanun ile, 242 ilk kademe belediyesinin tüzel kişiliği sona erdirilmiş ve bu belediyeler ya birleşerek bir belediye oluşturmuşlar ya da bir büyükşehir ilçe belediyesine katılmışlardır. İlk kademe belediyelerinden 32 tanesi yeni büyükşehir ilçe belediyesine dönüşmüş, 8 tanesi büyükşehir kapsamından çıkartılarak belde belediyesi ve 1 tanesi de köye dönüşmüştür. Nüfusu 2000'in altında olduğu tespit edilen 862 belde belediyesinin tüzel kişiliği kaldırılarak köye dönüştürülmüştür (Canpolat, 2009:541).

5747 say1lı Kanun, Ana Muhalefet Partisi tarafından iptali için Anayasa Mahkemesi’ne götürülmüştür. Anayasa Mahkemesi, beldelerin köye dönüştürülmesi düzenlemesi dışında, bu talebi reddetmiştir. Tartışmalı hale gelen bu konunun neticesinde, yüksek yargı organları kararları ile buna bağlı olarak seçim ve yürürlük konusu itibariyle Yüksek Seçim Kurulu'nun nihai kararıyla, Anayasa Mahkemesi'nin kararında istisna tuttuğu Adrese Dayalı Nüfus Kayıt Sistemi (ADNKS) sonuçlarına, yasal süresi içinde iptal davası açtığı tespit edilen 836 belediye, köye dönüştürülmekten kurtularak, seçimlere belediye olarak girmiştir (Zengin, 2014:101).

5747 sayılı Kanun ile yapılan asıl değişiklik, Arıkboğa'ya (2009:743) göre, büyükşsehirlerdeki ölçek reformudur. İlçesi olmayan bütün küçük ilk kademe belediyelerinin kaldırılmış olması, büyükşehir belediye meclislerindeki temsil adaletsizliğine neden olan dönemi de sona erdirmiştir.

\subsection{Sayılı Yasa ile Gelen Büyükşehir Belediye Modeli ve Devam Eden Reform Çalışmaları}

Küreselleşme sürecine paralel bir şekilde, tüm dünyada olduğu gibi Türkiye'de de yönetim paradigması değişmiştir. Özellikle yerel yönetim sistemi içerisinde büyük bir öneme sahip olan büyükşehir yönetimleri yeniden yapılanma sürecine girmiştir.

Türkiye'de yerel yönetimlerin özellikle büyükşehir belediye yönetimlerinin yeniden yapılandırılması, mevcut olan kurumsal yapının revize edilmesine yönelik model arayışları her zaman gündemde kalan önemli bir konudur (Bulut ve Yılmaz, 2019: 732). Türkiye, büyükşehir belediye yönetiminin kuruluşundan beri başta görev ve yetki paylaşımı olmak üzere planlamadan mali bölüşüme kadar pek çok konuda sorunla karşılaşmış ve sorunların çözümüne yönelik uygulanan modellerde zaman içerisinde köklü değişiklikler yapmak zorunda kalmıştır (Canpolat, 2010:45). Bu köklü değişimlerin son halkasını hiç şüphesiz 6 Aralık 2012 tarihinde

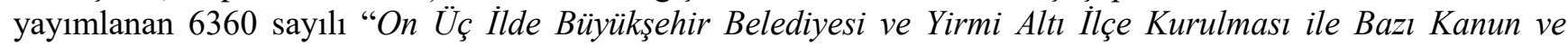
Kanun Hükmünde Kararnamelerde Değişiklik Yapılmasına Dair Kanun” oluşturmuşstur. 14 Mart 2013 tarihli ve 6447 sayılı Kanun'un 1. maddesiyle, bu Kanun'un başlı̆̆ında yer alan "On Üç" ibaresi "On Dört" olarak, "Yirmi Altı" ibaresi "Yirmi Yedi" olarak değiştirilmiştir (www.mevzuat.gov.tr).

6360 sayılı Kanun'un gerekçesi; kamu yönetiminde etkinliği ve verimliliği artırmak, vatandaşın yönetim sürecine daha fazla katılımını sağlamak ve artan beklentisini karşılamak, parçalı planlar yerine bütüncül planlar yapmak ve yönetsel kapasitesi düşük yerel yönetim birimlerinin sebep olduğu kaynak israfını önlemek olarak belirtilmiştir (Zengin, 2014:102; Karaarslan, 2013:139). Bunun yanı sıra, hem nüfus hem de alan bakımından optimal bir büyüklüğün sağlanması hedeflenilmiştir (Atmaca, 2013:178). 5216 Sayı1ı Kanun'un gerekçe ve hedefi ile bu anlamda benzerlik gösterdiği düşünülürse, bu ifadelerin aslında bir parça soyut olduğu söylenilebilir.

Yeni bir yönetim biçimi getiren 6360 sayılı kanunun çözüm üretmeyi hedeflediği sorun alanları ve konuları ölçek ekonomilerinden yeterince yararlanılamaması, kaynak israfının önlenemiyor olması, küçük ölçekli belediye ya da köylerin çevre, ulaşım vb. problemleri çözme konusunda kendi başlarına yeterince verimli olamamaları, planlamanın ve koordinasyonun sağlanamayışı ve mali kaynak yetersizlikleri olarak belirtilmiştir (Çelikyay, 2014:11). 2014 yılı yerel yönetim seçimlerinin ardından yürürlüğe giren 6360 sayılı kanun ile yapılan değişiklikler genel olarak şöyle sıralanabilir;

- 14 il belediyesi daha büyükşehir belediyesi yapılmış, sayısı 30'a çıkan büyükşehir belediyelerinin sınırları il mülki; ilçe belediyelerinin sınırları bu ilçelerin mülki sınırları olmuş,

- Büyükşehir Belediyesi olma koşulu, belediye nüfusunun 750.000'i aşmış olması yerine, il nüfusunun 750.000 üzerinde olması biçiminde değiştirilmiş,

- Büyükşehir olmayan illerdeki 559 belediye, nüfusu 2.000'in altında olduğu için köye dönüştürülmüş,

- 5747 sayılı Kanun'dan itibaren iki kademeli (büyükşehir ve ilçe belediyesi) olarak kurulan ve işleyen mevcut büyükşehir belediye modelinde, 2.000 nüfus şartına bağlı kalmaksızın, bu ikili modelden dolayı yeni büyükşehir belediyesi sınırları içinde kalan 1.076 belde belediyesi ile 16.500 köy tüzel kişiliğini kaybetmiş ve mahalleye dönüşmüştür (Zengin, 2014:103). 
- Büyükşehir Belediyesi olan yerlerde ilçe belediyesi olma nüfus kriteri 50.000'den 20.000'e düşürülmüş,

- 30 büyükşehir belediyesinde il özel idarelerinin tüzel kişiliklerine son verilmiş, kaldırılan il özel idarelerinin yerine bu illerde, valiliklere bağlı Yatırım İzleme ve Koordinasyon Başkanlıkları kurulmuş,

- Büyükşehir olan illere bağlı ilçelerin mülki sınırları içinde yer alan köy ve belde belediyelerinin tüzel kişiliği sona ermiş, köyler mahalle olmuş, belediyeler ise mahalleleri ile birlikte bağlı bulundukları ilçenin belediyesine katılmışlardır.

6360 sayılı Kanun ile yapılan değişikliklerin başında gelen, büyükşehir belediyelerinin bulunduğu illerde tüzel kişilikleri son bulan il özel idarelerinin yerine kurulan Yatırım İzleme ve Koordinasyon Başkanlığı (YİKOB)'nın görevleri şu şekildedir (3152 sayılı Kanun, md.28);

\begin{abstract}
"Büyükşehir belediyelerinin bulunduğu illerde kamu kurum ve kuruluşlarının yatırım ve hizmetlerinin etkin olarak yapılması, izlenmesi ve koordinasyonu, acil çağrı, afet ve acil yardım hizmetlerinin koordinasyonu ve yürütülmesi, ilin tanıtımı, gerektiğinde merkezi idarenin taşrada yapacă̆ yatırımların yapılması ve koordine edilmesi, temsil, tören, ödüllendirme ve protokol hizmetlerinin yürütülmesi, ildeki kamu kurum ve kuruluşlarına rehberlik edilmesi ve bunların denetlenmesini gerçekleştirmektir. Bakanlıklar ve diğer merkezi idare kuruluşları, kaynağını aktarmak şartıyla illerde yapacakları her türlü yatırım, yapım, bakım, onarım ve yardım işlerini bu başkanlık aracılığılyla yapabilirler. Bu işler karşılığl genel bütçe kapsamındaki kamu idarelerince yapılacak kaynak transferleri ödenek aktarması suretiyle, diğer kamu kurum ve kuruluşlarınca yapılacak kaynak transferleri ise tahakkuk işlemleri ile gerçekleştirilir. Genel bütçe kapsamindaki kamu idarelerince aktarılan tutarlardan yıl içerisinde harcanmayan kısımları ertesi yıl bütçesine devren ödenek kaydetmeye; diğer kamu kurum ve kuruluşlarınca aktarılan tutarları bir yandan genel bütçenin (B) işaretli cetveline gelir, diğer yandan Bakanlık bütçesinin ilgili tertiplerine ödenek kaydetmeye ve yıl içerisinde harcanmayan kısımlarını ertesi yll bütçesine devren gelir ve ödenek kaydetmeye İçişleri Bakanlı̆̆ yetkilidir".
\end{abstract}

Yatırım izleme ve koordinasyon başkanlığı tarafından, merkezi idarenin adli ve askeri teşkilat dışında taşradaki tüm birimlerinin hizmet ve faaliyetlerinin etkinliği, verimliliği ve kurumların stratejik plan ve performans programlarına uygunluğu ile ilgili hazırlanacak rapor, valinin değerlendirmesiyle birlikte Başbakanlığa ve bu kurumların bağlı veya ilgili olduğu bakanlığa gönderilir. Bu raporlar yıllık olarak hazırlanır ve takip eden yılın şubat ayı sonuna kadar yukarıdaki mercilere gönderilir.

5018 sayılı Kanun ve ilgili mevzuatta bu tür raporlamaların iç kontrol, iç denetim ve dış denetim kapsamında yapılacağının öngörülmüşken, taşrada kontrol ve denetim yetkisinin yeni oluşturulan birime devredilmesi ve düzenlenen raporun valinin görüşü alındıktan sonra Başbakanlığa ve ilgili bakanlığa gönderilmesinin mevzuata aykırı olduğunu ifade eden Ozansoy (2014), merkezi idarenin taşra teşkilatları için bu kapsamda denetim/değerlendirme raporlarının Başbakanlıktaki hangi kadronun değerlendireceği ve bu değerlendirme üzerine nasıl bir işlem yapacağını da ayrı bir sorun alanı olarak görmektedir (www.ahmetozansoy.com).

Yatırım izleme ve koordinasyon başkanlıkları, afet yardım, acil çağrı, yatırım izleme, rehberlik ve denetim, strateji ve koordinasyon ile idari müdürlükler kurabilir. Gerektiğinde geçici birimler kurulabilir. Yatırım izleme ve koordinasyon başkanlıklarının çalışma usul ve esasları İçişleri Bakanlığınca çıkarılacak yönetmelikle belirlenir. Yatırım izleme ve koordinasyon başkanlığının sevk ve idaresi, vali veya vali tarafından görevlendirilecek bir vali yardımcısı tarafından yerine getirilir. Maliye Bakanlığınca, yatırım izleme ve koordinasyon başkanlıklarının görev ve sorumluluklarını yerine getirebilmesi için her yıl İçişleri Bakanlığı bütçesine yeterli ödenek konulur. Gerektiğinde valilik, kadro, yer ve unvanlara bakılmaksızın ihtiyaç durumuna göre uzman, sözleşmeli personel ve memurları bu başkanlıklarda görevlendirmeye yetkilidir.

Kamu kurum ve kuruluşlarının 05.01.1961 tarihli ve 237 sayılı Taşıt Kanunu kapsamındaki araçlarının alımı, işletilmesi, bakım ve onarımı ile bürolarının ihtiyaçları; valilik ve kaymakamlık konutlarının yapım, bakım, işletme ve onarımı ile emniyet hizmetlerinin gerektirdiği harcamalar yatırım izleme ve koordinasyon başkanlığı tarafindan sağlanır.

İldeki kamu kurum ve kuruluşlarınca yürütülmesi gereken yatırım ve hizmetlerin aksadığının ve bu durumun halkın sağlı̆̆ı, huzur ve esenliği ile kamu düzeni ve güvenliğini olumsuz etkilediğinin vali veya ilgili bakanlığınca tespit edilmesi durumunda, vali uygun süre vererek hizmet ve yatırımın gerçekleştirilmesini ister. Hizmet ve yatırımın verilen sürede gerçekleşmemesi halinde, vali söz konusu yatırım ve hizmetin ildeki diğer kamu kurum ve kuruluşlarınca yerine getirilmesini isteyebileceği gibi yatırım izleme ve koordinasyon başkanlığı aracıllı̆ı̀la da yerine getirebilir. Yapılan veya yapılacak harcamalar karşıllı̆̆ tutarlar ilgili kurumun 
pay ve ödeneklerinden tahsis yapan kurum tarafından kesilerek İçişleri Bakanlığı'na veya hizmeti yerine getiren diğer kamu kurum ve kuruluşuna gönderilir. Bu fikra kapsamında İçişleri Bakanlığı'na ve diğer genel bütçeli idarelere aktarılan tutarların bu kurumların bütçeleriyle ilişkilendirilmesi birinci fikra hükümleri çerçevesinde, diğer kamu kurum ve kuruluşlarına aktarılan tutarların bütçeleriyle ilişkilendirilmesi bu kurumların tabi olduğu mevzuat hükümleri çerçevesinde gerçekleştirilir. Diğer genel bütçeli idarelere ilişkin bütçe işlemlerini yapmaya bu kurumların üst yöneticileri yetkilidir.

6360 sayılı Kanun (md.24) ile 5302 sayılı İl Özel İdaresi Kanununda (md.44) değişikliğe gidilerek, bütçenin kesinleşmesi konusunda il özel idaresi üzerinde İç İşleri Bakanlığı'nın yeni bir vesayet örneği ortaya konulmuştur. Bu değişiklik, yerel yönetimlerin merkezi yönetim karşısındaki özerkliğini azaltılmıştır (Günal vd., 2014:65). Oluşturulan yeni yapının işlevlerine bakıldığında valinin rolünün bu birim üzerinden yeniden tanımlandığı ve genel yetkilerinin operasyonel hale getirildiği anlaşılmaktadır (Koyuncu ve Köroğlu, 2012:4). Bu birimle valinin yönetsel olarak kapasitesi artırılmış, valilerin il özel idareleri aracılığı ile sahip oldukları yerel hizmetlerdeki vesayet yetkisi YİKOB ile daha da ağırlaştırılmıştır (Önez Çetin, 2015:263).

Tüzel kişiliği ve bütçesi olmayan bu birimlere 15.08.2016 tarihli ve 674 sayılı KHK'nın 35. ve 36. maddeleri ile 3152 sayılı İç İşleri Bakanlığ̣ Teşkilat ve Görevleri Hakkında Kanun'un YIKOB'larla ilgili 28/A maddesine kamu tüzel kişiliğini haiz ve özel bütçeli ibareleri eklenmiştir. Bu şekilde tüzel kişiliği ve bütçesi olmayan bu birimlere tüzel kişilik kazandırılmıştır (www.mevzuat.gov.tr). Diğer önemli bir değişiklik olan, 6360 sayılı Kanunla; otuz ilde köylerin ve kasaba belediyelerinin kaldırılıp ilçe belediyesinin bir mahallesi haline dönüştürülmeleri Avrupa Yerel Yönetimler Özerklik Şartı açısından eleştirilmektedir. Tesis edilen bu mahalleleri ilgilendiren kararların burada oturan halk tarafından değil, daha uzakta bulunan belediye meclisleri tarafından alınması "subsidiarite" ilkesine de ayrılık teşkil etmektedir (Gözler, 2013:76). İlgili kanunla çok sayıda yerel yönetim biriminin statüsünün sona ermesi ve buna bağlı olarak devir işlemlerinde yaşanan sorunlar, hizmet sunumunu daha da karmaşı hale getirmiştir (Özgür ve Savaş Yavuzçehre, 2016:924).

Büyükşehir olan illerde kırsal alan yönetimi kavramı hukuki anlamda tamamen ortadan kalkmıştır. Bir kentsel alan yönetimi olan büyükşehir belediyesinin görev ve yetki sahasının tüm il mülki sınırı olarak belirlenmesi, il sınırları içerisindeki kırsal alanların fiziki olarak olmasa da hukuki anlamda kentsel alanlara dönüşmesi anlamına gelmektedir. Bu da ayrı ve özel bir yerel yönetim şekli olan kırsal alan yönetimlerinin organik (il özel idaresi ve köy) ve faaliyetleri açısından son bulmasına, kentsel alan yönetimleri içerisinde değerlendirilmesine neden olmuştur. Kentsel alan yönetimleri ve kırsal alan yönetimleri karşlıklı işbirliği ve koordinasyon içerisinde, ancak ayrı bir organik yapı ve yönetsel mekanizmalar ile yönetilmesi ve bu yönde de hizmetlerine özel kaynaklar tahsis edilmesi ve bu kapsamda yetkilendirilmesi daha etkin ve verimli bir yerel yönetim mekanizmasının tesis edilmesine katkı sağlayacağı düşünülmektedir.

Mali imkânsızlıklar ve günümüz şartlarına uygun olmayan hukuki yapısı (442 sayılı köy kanunu) nedeniyle Avrupa Yerel Özerklik Şartı ve Türkiye Cumhuriyeti Anayasası'nın 127'nci maddesinin özüne uygun olmayan köy yönetimlerinin varlık yapısı, uygulamaları ve geleceği hakkında zaman zaman tartışmalar yaşanmaktadır (Mecek ve Uysal, 2015:198). İl özel idarelerinin görev ve yetkilerinin diğer yönetim birimlerinin (merkezi idare, belediyeler, köyler) görevlerini tamamlayıcı nitelikte olması ve yine diğer yönetim birimleri ile görevlerinin çakışması (Özer ve Akçakaya, 2014:149) da kırsal alan yönetimi birimlerinin etkinliği ve verimliliğinin sorgulanmasına neden olmaktadır. Ancak bu birimlerin (il özel idaresi ve köy) tamamen ortadan kaldırılması yerine görev ve yetkilerinin yeniden düzenlenmesi ve görevlerini yerine getirebilecekleri kaynaklar ile donatılmaları daha uygun ve yararlı olacağı kanaatine sahip olunmaktadır.

Kanun'un en çok tartışılan bir başka yönü de siyasal yapıya ilişkindir. Bu düzenlemenin aslında başkanlık sisteminin alt yapısını oluşturmaya yönelik olduğunu, bölge yönetimleri oluşturulmak üzere çıkarıldığı, aslında yerelde güçlü bir merkezileşmenin hedeflendiği, demokratik katılımı azaltacağı yönünde farklı bakış açıları bulunmaktadır (İzci ve Turan, 2013:135). Ayrıca 6360 sayılı Kanun sonrası büyükşehirlerin merkez ilçelerindeki nüfus artmış, diğer büyükşehir ilçelerinde ise nüfus azalmıştır (Yılmaz ve Sayın, 2018:1616). Bu durum zaten azalım yönünde olan kırsal kesimin nüfusunun daha da azalmasına sebebiyet vermiştir.

Büyükşehir Belediyesi Kanunu ve sonrasında gerçekleştirilen değişiklikler diğer yerel yönetim birimleri ile doğrudan ilişkilidir. Dolayısıyla büyükşehir uygulamasına yönelik tesis edilen model ile diğer birimler için öngörülen/öngörülecek modeler de yapılandırılmaktadır. Başka bir açıdan da yapılanması için büyükşehir belediyesi modelinin tam olarak olumlu ve olumsuz yönlerinin ortaya çıarak revize edilmesi beklenilmektedir. Örneğin 2004-2006 y1llarında yerel yönetimler (il özel idaresi, belediye, büyükşsehir belediyesi) ile ilgili kanunlar yeniden hazırlanmıştır. Ancak 1924 tarihinde yürürlüğe giren ve günümüz koşullarını karşılamaktan uzak olan yeni köy kanunu yürürlüğe konmamıştır. Büyükşehirlerde köy tüzel kişiliğinin 2012 yılı itibariyle 
hukuken ve 2014 yılında yeni mahalli idareler seçimleri ile fiilen sona erdirilmiş olması bu alanlarda yeni bir gözlem ve değerlendirme sürecini ortaya çıkarmıştır. Bu da yeni bir köy kanununun yayınlanmasını geciktirmektedir. Ayrıca tüzel kişiliği olmamasına rağmen yerel katılım açısından önemli bir mekanizma olan mahalle muhtarlıkları ile ilgili güncel bir düzenleme yapılması ihtiyacının da bu süreç ile ilgili olduğu düşünülmektedir. Kentsel alan yönetimlerinin "yerel katılım” ile ilgili önemli bir unsur olan "mahalle yönetimleri” ile ilgili çalışmalarda (Örneğin Yllmaz ve Mecek, 2019:791-793) bazı model önerileri yer alsa da ülke gündeminde bu konuda etkin bir kamuoyu oluşmamıştır.

\section{SONUÇ VE DEĞERLENDİRME}

Türkiye'de bugünkü anlamda olmasa da büyük yerleşim yerleri için model arayışlarının Osmanlı dönemine kadar dayandığını söylemek mümkündür. Bu arayışların Cuhuriyet döneminde de devam ettiği görülmektedir. 1982 Anayasası'na kadar olan süreçte farklı model ve yapılanmalar dile getirilmekle beraber, doğrudan büyük şehir yönetimlerinin önünü açan düzenleme, 1982 Anayasası'nın 127. maddesi ile olmuştur. Anayasanın “...büyük yerleşim yerleri için kanunla özel yönetim biçimleri kurulabilir”, hükmü uyarınca, 3030 say1lı "Büyükşehir Belediyelerinin Yönetimi Hakkında Kanun" çıkarılmış ve böylece Türkiye'de büyükşehir modeli yasal yapıya kavuşmuştur. Ancak büyük şehirlere olan göçlerin fazla olması ve bu alanlarda aşırı nüfüs artışının yaşanması, beraberinde yönetim, alt yapı ve çevre sorunlarını daha fazla gündeme getirdiği için büyük şehir yönetimlerine ilişkin model arayışlarına devam edilmiş, hatta günümüzde de farklı biçimlerde devam edilmektedir. 5216 sayılı Büyükşehir Belediye Kanununun kabul edilmesi ve hayata geçirilmesi de bu arayışın bir sonucudur.

$\mathrm{Bu}$ yasa, katılımcı ve çok aktörlü bir yönetim anlayışını benimsemekle birlikte, kamu hizmetlerinin sunumunda etkinliği yeterince sağlayamaması, beraberinde yeni düzenlemeleri gündeme getirmiş ve bu yasada bazı değişiklikleri öngören ve büyükşehir yönetimlerinin sınırını il sınırına taşıyan yeni bir modelin öngörüldüğ̈̈ 6360 sayılı Kanun kabul edilmiştir. Bu düzenleme ile idari ve mali yapıda, katılım, hizmet sunumu, imar ve planlama düzeninde önemli değişiklikler öngörülmüştür. Yeniden yapılanma sürecinde yerel yönetimlerin yetki, görev ve hizmet alanları tekrardan belirlenmiştir. Ayrıca hizmet üreten ve bu hizmeti sunan kuruluşların yapısında da önemli değişimler meydana gelmiştir. Sınırı il sınırı olan büyük şehirlerin kapsamındaki il özel idareleri, belde ve köylerin tüzel kişilikleri sona ermiş ve yeni bir model doğmuştur.

$\mathrm{Bu}$ değişim bir bakıma yerel ve küresel etkiler çerçevesinde sosyo-ekonomik yapılardaki değişim ve dönüşüme göre şekillenmektedir. Dolayısıyla değişim aslında ucu açık ve yeni gelişmelere göre yeni arayışları içinde barındırmaktadır. Diğer bir ifade ile kentler geliştikçe kentin ihtiyaçları da değişmektedir. Bu nedenle büyükşehir yönetimlerine ilişkin en ideal model arayışları da devam etmektedir. Bu bağlamda, "Nasıl bir büyük şehir yönetim modeli?" sorusu hala gündemdeki yerini korumaktadır. Nitekim 2012 yılı değişiklikleri ile son hali verilen Türkiye'deki büyükşehir kent yönetimi modeli, başta etkinlik ve kaynak yönetimi açısından olmak üzere bir çok yönüyle tartışılmaya devam etmektedir. Özellikle büyükşehir-ilçe belediyeleri arasındaki ilişkiler, belediye gelirlerinin arttırılması, istihdam sorunlarının çözümü, yerel kalkınma, dezavantajlı grupların desteklenmesi, kaynakların etkin ve verimli kullanılması konularındaki tartışmaların yanı sıra 2019 yerel seçimleri ile birlikte belediye organları arasındaki görev ve yetki paylaşımı (özellikle başkan ve meclis arasındaki) da farklı tartışmalara konu olmaktadır. Hatta yeni yasal düzenlemelerin yapılabileceği ve yeni model arayışlarının devam edeceği izlenemi oluşmaktadır. Özellikle büyükşehirlerin yönetiminde ölçek sorunu, kaynak ve yetki paylaşımı ile ilgili yaşanan değişim ve dönüşümler konusunda yeni düzenlemelere ihtiyaç olduğu düşünülebilir. 


\section{KAYNAKÇA}

ARIKBOĞA, Erbay (2009), "Ölçek Reformunun Büyükșehir Belediye Meclislerindeki Temsil Adaletine Olumlu Etkileri”, Ulusal Kalkınma ve Yerel Yönetimler: 4. Ulusal Yerel Yönetimler Sempozyumu Bildiriler Kitabı, TODAİE Yayını, Ankara, C.2, ss.737-754.

ARIKBOĞA, Erbay (2012), "Büyükşehir Belediye Modeli ve Reform”, Marmara Sosyal Araştırmalar Dergisi, S.2, ss.1-32.

ATMACA, Yıldız (2013), “Optimal Belediye Büyüklügü ve Yeni Büyüksehir Belediye Yasası”, Çankırı Karatekin Üniversitesi İktisadi ve İdari Bilimler Fakültesi Dergisi, S.3(2), ss.168-185.

BAYRAKCI, Erdal (2019), Yerel Yönetimler Ders Notları, (Yazarın Kendi Yayını), Konya.

BULUT, Yakup (1995), “Belediyelerin Yapısı ve Yeniden Düzenlenmesi”, Yayınlanmamış Yüksek Lisans Tezi, Marmara Üniversitesi Sosyal Bilimler Enstitüsü, İstanbul.

BULUT, Yakup (1999), “Büyükşehir Yönetimlerine Kentsel Alt Örgütlenmelerin (Mahalle, STK...) Katılımı: Gaziantep Büyükşehir Belediyesi Örneği”, Yayınlanmamış Doktora Tezi, Marmara Üniversitesi Sosyal Bilimler Enstitüsü, İstanbul.

BULUT, Yakup ve YILMAZ, Vedat (2019), “Türkiye'de 6360 Sayll Yasa Sonrası İ Özel İdarelerinin Geleceği”, Türkiye Vizyonu Multidisipliner Çalışmalar (Ed. Bülent Kırmızı ve Bahar İşigüzel), ss.731-746, Ekin Yayınevi, Bursa.

CANPOLAT, Hasan (2009), "Türk Yerel Yönetim Sisteminde Ölçek Sorunu ve Son Dönemde Yapılan Düzenlemelerin Değerlendirilmesi”, Ulusal Kalkınma ve Yerel Yönetimler-I, TODAİE Yayınları, Ankara, ss.529-545.

CANPOLAT, Hasan (2010), "Türkiye'de Son Dönem Yerel Yönetim Reformlarının Yeni Kamu İşletmeciliği ve Küreselleşme Bağlamında Değerlendirilmesi”, Türkiye'de Yerel Yönetimlerin Sorunları ve Geleceği (Ed. Nihat Falay, Ahmet Kesik, Murat Çak ve Mehmet Karataş), Seçkin Yayınları, Ankara, ss.27-61.

ÇELIKYAY, Hicran (2014), Değişen Kent Yönetimi ve 6360 Sayılı Büyükşehir Yasası, SETA Siyaset, Ekonomi ve Toplum Araştırmaları Vakfı Yayını, Ankara.

ÇUKURÇAYIR, Mehmet Akif (1994), "Büyükşehir Belediyelerinin Mahalli Hizmetlerin Verimliliğine Etkileri ve Konya Büyükşehir Belediyesinin Beş Yılı”, Yayınlanmamış Yüksek Lisans Tezi, Selçuk Üniversitesi Sosyal Bilimler Enstitüsü, Konya.

ÇUKURÇAYIR, Mehmet Akif (2011), Yerel Yönetimler Kuram Kurum ve Yeni Yaklaşımlar, Çizgi Kitabevi, Konya.

DEDEOĞLU, Erdoğan (2011), "Büyükşsehir Belediye Yönetimlerine Genel Bakış", Dış Denetim Dergisi, S.4, ss.130-135.

DÖNMEZ, Demet (2018), “Türkiye'de büyükşehir yönetimleri ve büyükşehirlerin yeniden yapılandırllmasına ilişkin model arayışları üzerine bir inceleme”, Yayınlanmamış Doktora Tezi, Hatay Mustafa Kemal Üniversitesi Sosyal Bilimler Enstitüsü, Hatay.

EKE, A. Erkan (1982), Anakent Yönetimi ve Yönetimlerarası İlişkiler, Ankara Üniversitesi Siyasal Bilgiler Fakültesi Yayınları, Ankara.

ERYILMAZ, Bilal (2012), Kamu Yönetimi, Umuttepe Yayınları, Kocaeli.

GÖZLER, Kemal (2013), "6360 Sayılı Kanun Hakkında Eleştiriler: Yirmi Dokuz İlde İ Özel İdareleri ve Köylerin Kaldırlması ve İlçe Belediyelerinin Büyükşehir Illçe Belediyesi Haline Dönüştürülmesi Anayasamiza Uygun Mudur?", Legal Hukuk Dergisi, S.11(122), ss.37-82.

GÜNAL, Alpay, ATVUR, Senem ve OKUDAN, Kadriye (2014), “6360 Sayılı Yasanın Yerelleşme Bağlamında Değerlendirilmesi”, Süleyman Demirel Üniversitesi İktisadi ve İdari Bilimler Fakültesi Dergisi, S.19(3), ss.55-70.

IZCI, Ferit ve TURAN, Menaf (2013), “Türkiye'de Büyükşehir Belediyesi Sistemi ve 6360 Sayıl Yasa ile Büyükşsehir Belediyesi Sisteminde Meydana Gelen Değissimler: Van Örneği”, Süleyman Demirel Üniversitesi İİBF Dergisi, S.18(1), ss.117-152. 
KARAARSLAN, Mehmet (2013), "Nasıl Bir Yerel Yönetim? 6360 Sayıl Kanun Üzerine Bir Değerlendirme”, Dicle Üniversitesi Hukuk Fakültesi Dergisi, S.17-18(26-27-28-29), ss.123-162.

KAVRUK, Hikmet (1999), “Türkiye'de Anakent Belediyeciliği ve Kent Hizmetlerinin Yönetimi, Yabancı Ülke Örnekleriyle Karşılaştırma ve Bir Model Önerisi”, Yayınlanmamış Doktora Tezi, Gazi Üniversitesi Sosyal Bilimler Enstitüsü, Ankara.

KELEŞ, Ruşen (2000), Kentleşme Politikası, İmge Kitabevi, Ankara.

KELEŞ, Ruşen (2009), Yerinden Yönetim ve Siyaset, Cem Yayınevi, İstanbul.

KELEŞ, Ruşen (2011), Yerinden Yönetim ve Siyaset, Cem Yayınevi, İstanbul.

KOYUNCU, Emre ve KÖROĞLU, N. Tunga (2012), Büyükşehirler Tasarısı Üzerine Bir Değerlendirme, Türkiye Ekonomi Politikaları Araştırma Vakfı Yayını, Ankara.

MECEK, Mehmet ve UYSAL, Yusuf (2015), "Yerel Hizmetlerin Ifasında Köylerde Personel İhtiyacı ve İstihdamı: Afyonkarahisar İli Örneği”, 9. Kamu Yönetimi Sempozyumu (KAYSEM) Bildiriler Kitabı (Ed. Selma Karatepe, Ender Akyol, Canan Emek İnan, Işıl Arpacı, Ayşe Çolpan Kavuncu, Nazlı Nalcı Arıbaş), 7-9 Mayıs 2015, Malatya, ss.197-212.

NADAROĞLU, Halil (1989), Mahalli İdareler, Beta Yayınları, İstanbul.

OLGUN, Hürriyet (2006), “Türkiye'de Büyükşehir Belediyeleri ve Küreselleşme Sürecine Eklenmeleri”, Sosyo Ekonomi Dergisi, S.2(4), ss.109-128.

ÖKMEN, Mustafa ve PARLAK, Bekir (2008), Kuramdan Uygulamaya Yerel Yönetimler: İlkeler Yaklaşımlar ve Mevzuat, Alfa Akademi Yayınları, İstanbul.

ÖNER, Şerif (2006), Yeni Mevzuat Çerçevesinde Türkiye'de Belediye Yönetimi, Nobel Yayınları, Ankara.

ÖNEZ ÇETIN, Zuhal (2015), “Türkiye'de İl Özel İdaresi Sisteminin Dönüşümü ve 6360 Sayılı Kanunun Dönüşüme Etkileri”, Süleyman Demirel Üniversitesi İktisadi ve İdari Bilimler Fakültesi Dergisi, S.20(2), ss.247-266.

ÖZÇELIK, Yusuf (2014), “Büyükşehir Belediyesi ile İlçe Belediyeleri Arasındaki İlişkiler”, TAAD, S.5(19), ss.1117-1142.

ÖZDEMIR, Serkan ve MEŞHUR, Mehmet Çağlar (2011), “5216 Sayılı Büyükşehir Belediye Yasası'nın Belde Belediyelerinin Planlama Süreçleri Üzerinde Yarattığı Etkiler”, MEGARON, S.6(3), ss.171-183.

ÖZER, Mehmet Akif ve AKÇAKAYA, Murat (2014), Yerel Yönetimler: Teorik Boyut, Gazi Kitabevi, Ankara.

ÖZGÜR, Hüseyin ve SAVAŞ YAVUZÇEHRE, Pınar (2016), “Türkiye’nin Büyükşehir Belediyesi Sistemi: 1982-2015”, Çankırı Karatekin Üniversitesi Sosyal Bilimler Enstitüsü Dergisi, S.7(1), ss.903-926.

SEZER, Yasin (2007), “Belediyelerde Birleşme ve Katılma Uygulamaları”, Yerel Yönetimler Üzerine Güncel Yazlar- II (Ed. Hüseyin Özgür ve Muhammet Kösecik), Nobel Yayınları, Ankara, ss.143-165.

ŞENGÜL, Ramazan (2010), Yerel Yönetimler, Umuttepe Yayınları, Kocaeli.

TORTOP, Nuri (1991), Mahalli İdareler, TODAİE Yayınları, Ankara.

TORTOP, Nuri, AYKAÇ, Burhan, YAYMAN, Hüseyin ve ÖZER, Mehmet Akif (2008), Mahalli İdareler, Nobel Yayınları, Ankara.

TURAN, Ali Eşref (2008), Türkiye'de Yerel Seçimler, İstanbul Bilgi Üniversitesi Yayınları, İstanbul.

ULUSOY, Ahmet ve AKDEMIR, Tekin (2001), Mahalli İdareler, Seçkin Yayınları, Ankara.

YILMAZ, Vedat (2018), “6360 Sayıl Yasa İle Uygulamaya Konulan Büyükşehir Modelinin Yerel Halka Yansimalarl: Hatay, Malatya, Manisa ve Van Büyükşehir Belediyesi", Journal of Social and Humanities Sciences Research, S.5(30), ss.4364-4378.

YILMAZ, Vedat ve MECEK, Mehmet (2019), “Türkiye'de Mahalle Yönetimlerinin Tarihsel Gelişimi ve Hukuki Statüsü”, İdealkent Dergisi, S.10(27), ss.769-799. 
YILMAZ, Vedat ve SAYIN, Ahmet Kenan (2018), "6360 Sayılı Yasa Sonrası İlçe Büyükşehir Belediyelerindeki Nüfus Değişimi Üzerine Bir Araştırma: Malatya Büyükşehir Belediyesi Örneği”, Atlas International Refereed Journal on Social Sciences, S.4(15), ss.1615-1627.

ZENGìN, Ozan (2014), “Büyükşehir Belediye Sisteminin Dönüşümü: Son On Yılın Değerlendirmesi”, Ankara Barosu Dergisi, S.2, ss.91-116.

www.ahmetozansoy.com (Erişim Tarihi: 21.11.2014).

www.mevzuat.gov.tr (Erişim Tarihi: 13.06.2015).

1580 sayıl1 mülga Belediye Kanunu (14.04.1930 tarih ve 1471 sayıl1 Resmi Gazete).

3030 sayı1ı mülga Büyükşehir Belediyelerinin Yönetimi Hakkında Kanun (09.07.1984 tarih ve 18453 say1lı Resmi Gazete).

3152 sayılı mülga İç İşleri Bakanlığı Teşkilat ve Görevleri Hakkında Kanun (23.02.1985 tarih ve 18675 say1lı Resmi Gazete).

5216 say11 Büyükşehir Belediye Kanunu (23.07.2004 tarih ve 25531 say1lı Resmi Gazete).

5302 sayı1ı İl Özel İdaresi Kanunu (04.03.2005 tarih ve 25745 sayılı Resmi Gazete).

5393 sayıl1 Belediye Kanunu (13.07.2005 tarih ve 25874 sayılı Resmi Gazete).

5747 sayılı Büyükşehir Belediyesi Sınırları İçerisinde İlçe Kurulması ve Bazı Kanunlarda Değişiklik Yapılması Hakkında Kanun (22.03.2008 tarih ve 26824 sayılı Resmi Gazete).

6360 sayı1ı On Dört İlde Büyükşehir Belediyesi ve Yirmi Yedi İlçe Kurulmasi ile Bazi Kanun ve Kanun Hükmünde Kararnamelerde Değişiklik Yapilmasina Dair Kanunu (06.12.2012 tarih ve 28489 say1l Resmi Gazete).

6552 sayılı İş Kanunu ile Bazı Kanun ve Kanun Hükmünde Kararnamelerde Değişiklik Yapılması ile Bazı Alacakların Yeniden Yapılandırımasına Dair Kanun (11.09.2014 tarih ve 29116 sayılı Resmi Gazete). 